\title{
ESPACIALIDADE INFANTIL: UMA ANÁLISE DAS RELAÇÕES ENTRE AS CRIANÇAS E A PRAÇA DO CENTENÁRIO EM PRESIDENTE PRUDENTE - SP
}

\author{
Beatriz de Stefani Cardoso, Victor Martins de Aguiar, Yeda Ruiz Maria \\ Universidade do Oeste Paulista - UNOESTE, Presidente Prudente, SP. E-mail: biastefanicardoso@gmail.com
}

\section{RESUMO}

O espaço público é importante para a criação de laços entre as pessoas, mas esse tem papel fundamental no desenvolvimento das relações sociais e na formação de uma consciência cidadã nas crianças. Diversos trabalhos têm discutido nos últimos anos a importância de se pensar as cidades como instrumentos de educação e cidadania, além das diretrizes projetuais que devem ser tomadas para potencializar essas relações. Este artigo busca estabelecer uma análise referente às relações entre os espaços públicos e as crianças. Para isso, utilizou-se do estudo de caso da Praça do Centenário, inaugurada em 2018 e localizada no Parque do Povo, em Presidente Prudente - SP. Foram realizadas leituras sobre as políticas públicas infantis existentes na cidade e, através do levantamento in loco da infraestrutura da praça, relacionou-se estas etapas a fim de analisar quantitativa e qualitativamente os equipamentos presentes nela, bem como o uso por crianças. Desse modo, a metodologia adotada para a realização desta pesquisa consistiu em revisões bibliográficas e documentais, levantamentos e análises do estudo de caso e sobre como os espaços públicos são e estão sendo projetados, considerando o aprimoramento de seus potenciais educadores para as crianças.

Palavras-chave: Crianças, Espaços educacionais, Espaços públicos, Infraestrutura, Presidente Prudente - SP.

\section{CHILDREN'S SPATIALITY: AN ANALYSIS OF THE RELATIONS BETWEEN CHILDREN AND THE PRAÇA DO CENTENÁRIO IN PRESIDENTE PRUDENTE - SP}

\begin{abstract}
Public space is important for the creation of bonds between people, but it has a fundamental role in the development of social relations and in the formation of a citizen conscience in children. Several studies have discussed in recent years the importance of thinking of cities as instruments of education and citizenship, as well as the design guidelines that should be taken to enhance these relationships. This article seeks to establish an analysis regarding the relations between public spaces and children. For this, it was used the case study of the Praça do Centenário, inaugurated in 2018 and located in Parque do Povo, in Presidente Prudente - SP. Readings on existing children's public policies in the city were carried out and, through on-site survey of the square's infrastructure, these steps were related in order to analyze quantitatively and qualitatively the equipment present in it, as well as the use by children. Thus, the methodology adopted for this research consisted of bibliographic and documentary reviews, surveys and analysis of the case study and on how public spaces are and are being designed, considering the improvement of their educative potentials for children.
\end{abstract}

Keywords: Children, Educational spaces, Public spaces, Infrastructure, Presidente Prudente - SP

\section{INTRODUÇÃo}

Para discutir, analisar e entender as relações entre os espaços públicos e as crianças, é necessário primeiramente compreender a importância da cidade no desenvolvimento infantil. Até o século XIX, a rua era o espaço de 
socialização tanto de crianças como de adultos e, como Vicente (2018) expõe, a cidade é um importante meio de educação, desenvolvimento e construção social. Porém, com o crescimento das cidades, foram surgindo algumas segregações socioespaciais e a relação criança versus cidade sofreu alterações (OLIVEIRA, 2004).

Como pontua Loeb (2019), sem planejamento, a expansão urbana ocorreu de forma fragmentada e sem integridade, com centralidades limitadas e falta de espaços públicos de qualidade nas cidades. Para as crianças, tais aspectos acabam resultando em ambientes insalubres e inseguros, opções limitadas para circular e brincar, interações limitadas às redes sociais, serviços e economia local.

A partir dessa lógica, a criança pode ser considerada um indicador ambiental sensível, pois em cidades saudáveis e seguras, elas são vistas brincando livremente e passeando sozinhas pelas ruas; portanto, uma cidade segura às crianças, é segura também a todos os cidadãos (VICENTE, 2018).

O contrário de tal situação também pode ser observado, como explica Loeb (2019), as cidades, quando inseguras e falhas, podem ser danosas à infância, e isso pode ser observado principalmente nas localidades onde se tem a completa ausência de infraestrutura; problemas econômicos, conflitos armados e violência na comunidade afetam não somente os adultos, mas também o desenvolvimento das crianças, pois estas são mais vulneráveis. 0 autor também destaca como as crianças são as mais afetadas por essas problemáticas urbanas e pela falta de políticas públicas, citando o caso das favelas onde a desigualdade e pobreza operam de forma mais severa, pois as crianças vivem em um ambiente sujeito a constantes níveis altos de estresse.

Essas desigualdades, unidas a uma gestão que não busca qualificar os espaços públicos para as crianças, oferecendo proteção e ludicidade, acabam por agravar ainda mais suas problemáticas, o que aumenta as diferenças entre as classes sociais, étnicas e econômicas (LOEB, 2019). Isso acaba criando um cenário de vulnerabilidade e insegurança, onde cabe uma pergunta fundamental para entender a relação das crianças com a cidade e os espaços públicos na contemporaneidade: os adultos estão permitindo a presença e a interação da criança com esses espaços? E se não, para onde esse público é deslocado, em detrimento de uma maior "segurança"? Nesse questionamento, é essencial não apenas uma relação com os espaços construídos, mas também como essas crianças são vistas dentro da sociedade (VICENTE, 2018).

E é com o início da discussão sobre a insegurança que se começa a observar o afastamento das crianças da cidade, principalmente as de classes mais altas. As principais motivações acerca desse afastamento se apoiam também no novo modo de vida conectado às redes sociais e a internet, e no comodismo fruto dos processos dos quais a sociedade contemporânea enfrenta (GADELHA, 2019).

Como elucida Gadelha (2019), é a partir do momento que se verifica o afastamento das crianças dos espaços públicos, gerado pelos adultos, que se percebe a problemática na qual as cidades (sobretudo de médio e grande porte) se encontram, pois é necessário à sua presença e participação na vida urbana para que as relações entre elas e as urbes sejam criadas.

Para alcançar a referida segurança, os adultos acabam por tornar as crianças reféns a esses espaços segregados, destinados exclusivamente a elas: "infantis", fechados, artificiais, homogêneos, supervisionados e controlados por adultos. Esses espaços não apresentam diversidade, estímulo ou risco, o que acaba minando a criatividade e a infância em si (VICENTE, 2018).

Esse afastamento é preocupante, já que as crianças representam o futuro de sua sociedade e, no momento em que elas não conseguem (quando adultas) se identificar com a suas cidades e relações, essas áreas estão fadadas ao abandono e ao apagamento das suas condicionantes locais, tornando-se assim apenas receptáculos de uma vida urbana mecânica e alinhada aos padrões da globalização. As praças públicas e os parques infantis também sofrem com o abandono do público e do poder municipal, e por isso, muitas vezes, acabam sendo utilizados para fins ilícitos (GADELHA, 2019; OLIVEIRA, 2004).

Porém, o tema da criança na cidade vem ganhando importância nas últimas décadas exatamente pela retirada das crianças da vida urbana, que "desaparecem" das cidades, no que Sarmento (2019) descreve em um deslocamento casa-escola-shopping. Assim, ao isolá-las do meio urbano, perde-se a conexão entre a criança e o espaço público, sendo esta fundamental para o 
condicionamento de uma boa infância contemporânea.

Nos últimos anos têm sido publicados diversos trabalhos ${ }^{1}$ sobre a necessidade do recultivo das relações entre as cidades e as crianças, devido ao surgimento dessas problemáticas urbanas relacionadas ao desenvolvimento infantil, como explica Meira (2011). Por exemplo, em alguns trabalhos sobre o conceito das cidades educadoras ${ }^{2}$, o objetivo é tornar as crianças protagonistas da vida urbana, de forma que os autores examinam como as cidades se esqueceram das crianças.

Os espaços públicos estão no centro dos debates sobre as cidades contemporâneas, bem como a infância está no centro dos debates sobre políticas públicas, sobretudo por serem temas de grande potencial transformador da sociedade. Sob a perspectiva de transformação das cidades brasileiras em territórios mais justos e democráticos para as gerações futuras, torna-se necessária a união desses dois temas: espaço público e infância (NOSEK, 2018, p. 13).

Alguns autores também vêm analisando o comportamento de crianças para estabelecer características físicas nos espaços que mais as atraem e melhoram seu desenvolvimento interpessoal, intrapessoal e espacial na cidade. Luz e Kuhnen (2013), através de levantamentos e observações, determinam que fatores como a disponibilidade de equipamentos, sua manutenção constante, vegetação, e entre outros aspectos, interferem diretamente no comportamento de uso dos espaços pelas crianças. Nas praças em que havia espaços

\footnotetext{
${ }^{1}$ Alguns dos artigos sobre o assunto são: Uso dos espaços urbanos pelas crianças: uma revisão (LUZ; RAYMUNDO; KUHNEN, 2010); Espaços Públicos: suas potencialidades educadoras e a construção da cidadania (MERLIN; QUEIROZ, 2014); Infância e cidade: restrições e possibilidades (SARMENTO, 2018).

${ }^{2}$ De acordo com a Asociación Internacional de Ciudades Educadoras (2012), as cidades são educativas por si, mas elas tornam-se educadoras quando assumem essa intenção "consciente de que suas propostas têm consequências em atitudes e convivências e geram novos valores, conhecimentos e habilidades".
}

planejados de forma direcionada e em condições de manutenção mais adequadas, os autores perceberam que as crianças permaneceram por mais tempo em uma mesma atividade e setor, ou seja, se concentraram por mais tempo brincando no playground e na quadra poliesportiva.

Por outro lado, nos locais que apresentaram condições de manutenção e disponibilidade de equipamentos menos adequados, as crianças tenderam a explorar mais outros setores e a permanecer por menos tempo numa mesma brincadeira, sobretudo quando este mesmo local não dispunha de vegetação abundante (LUZ; KUHNEN, 2013, p. 558).

Mekideche (2004) afirma que o parque infantil, conhecido também por playground, é um dos primeiros lugares onde a criança pode interagir umas com as outras e com os adultos, além do seu círculo familiar, o que contribui não somente para com um primeiro contato com as diversidades, mas também com sua educação e aprendizado enquanto ser humano. Além disso, esses parques ainda propiciam um contato com a natureza e a cidade em si, incompatível com a vida dentro dos apartamentos e condomínios fechados, resultantes do modo de viver das sociedades urbanas das últimas décadas.

Já outros trabalhos apresentam como foco principal as relações das crianças, principalmente aquelas com idade entre 0 e 6 anos, período da Primeira Infância, pois elas são as mais vulneráveis aos efeitos negativos de um ambiente urbano com má qualidade de vida, problemas de mobilidade, má qualidade do ar e alimentação, da violência, insegurança e do abandono. Alguns estudos provaram que ter um ambiente seguro nos seis primeiros anos de vida pode gerar melhores resultados em sua saúde física e mental, maior capacidade de aprendizado e melhora em seus relacionamentos interpessoais (LOEB, 2019).

Outros autores também começaram a discutir o planejamento das cidades. Como explicam Dias e Ferreira (2015), no planejamento das cidades contemporâneas, não são levados em consideração os desejos e as necessidades de 
todos os grupos sociais, se distanciando de seus "consumidores", principalmente das crianças. Aqueles que ocupam os cargos de poder, muitas vezes, não são receptivos às demandas e preocupações desse público, pois eles são vistos apenas como um reflexo dos pais, um subproduto dos adultos produtivos, eleitores e, portanto, efetivamente cidadãos, permanecendo assim "invisíveis", sem direito à participação ativa.

Segundo o artigo 227 da Constituição Federal do Brasil (1988, não paginado), é dever da família, do Estado e da sociedade como um todo, assegurar à criança o direito à vida, à saúde, à alimentação, à educação, ao lazer, à profissionalização, à cultura, à dignidade, ao respeito, à liberdade e à convivência familiar e comunitária, além de colocá-la a salvo de toda forma de negligência, discriminação, exploração, violência, crueldade e opressão.

Outra lei importante sobre os direitos da criança é o Estatuto da Criança e do Adolescente ECA (Lei $\left.N^{\circ} 8.069,1990\right)$, principal instrumento normativo do Brasil sobre os direitos da criança e do adolescente. O ECA incorporou e ajudou a concretizar as diretrizes definidas pelo artigo 227 da Constituição Federal sobre os direitos das crianças, conforme anteriormente abordado. $\mathrm{O}$ Estatuto inova ao tratar crianças e adolescentes como sujeitos de direitos, além de reafirmar a responsabilidade da família, sociedade e do Estado em garantir as condições para o pleno desenvolvimento dessa população (BRASIL, 1990).

Porém é verificado que não existem, na grande maioria das cidades, estatutos sobre a criança nos espaços públicos com direcionamentos específicos em como eles podem potencializar a sua função educadora e fomentadora de cidadania. Para esse público, sequer são citadas as medidas necessárias para acolher e promover a segurança necessária. 0 que é observado no caso da cidade de Presidente Prudente - SP, onde seu Plano Diretor (2018), apenas cita que a cidade deve promover assistência, amparo e cuidado a crianças e outros públicos, como adolescentes, idosos, ou pessoas em situação de vulnerabilidade. Não há especificação sobre o papel do Plano Diretor para o público infantil ou acerca das políticas públicas que precisam ser desenvolvidas para acolher e potencializar seu desenvolvimento.

Levando-se em conta as questões tratadas, este artigo analisou as condições ligadas às relações entre os espaços públicos $e$ as crianças, adotando como estudo de caso a Praça do Centenário, localizada no Parque do Povo, em Presidente Prudente - SP, considerando a sua ausência de mobiliários infantis e o descaso público com a praça.

\section{MÉTODOS}

A pesquisa se amparou a partir de revisões bibliográficas, de análises, e de levantamentos documentais, através da utilização de recursos e plataformas online. Para o desenvolvimento deste estudo, foram utilizados materiais, artigos e trabalhos científicos, desenvolvidos sobre a escala e as necessidades dos espaços urbanos para o pleno desenvolvimento e integração das crianças. Com intuito de contextualizar a pesquisa à cidade e suas relações com o público em estudo, também foram analisados documentos e leis da cidade de Presidente Prudente - SP, seguido de correspondência com a Praça do Centenário, objeto de estudo.

Na Praça do Centenário foram realizados levantamentos e avaliações acerca do estado de conservação da infraestrutura e, se ela corresponde às necessidades das crianças. As informações foram inicialmente obtidas por meio digital, em virtude das restrições da pandemia de COVID-19, através de imagens do Google Earth, posteriormente editadas e inseridas neste artigo. Em seguida foram realizados levantamentos in $100^{3}$ da praça, sendo analisados aspectos quantitativos e qualitativos acerca de sua arborização, áreas verdes, áreas pavimentadas, iluminação, mobiliários (como bancos, bebedouros, lixeiras), mobiliários educativos, esportivos e infantis, informações estas inseridas em uma tabela. Durante o levantamento também foram produzidas as imagens que aparecem neste artigo, devidamente editadas ${ }^{4}$.

Todas as informações analisadas foram retiradas das imagens, mapas e dados, com o intuito de atingir os objetivos da pesquisa, contribuindo para a uma análise sobre o estado dos equipamentos presentes na Praça do Centenário e a relação de uso das crianças.

\footnotetext{
${ }^{3}$ Realizados seguindo todos os protocolos de biossegurança contra a transmissão do vírus da COVID-19, conforme recomendação da Universidade do Oeste Paulista - UNOESTE e da Organização Mundial da Saúde - OMS.

${ }^{4}$ Foram preservadas as identidades das crianças e adultos que aparecem nas fotos obtidas ao decorrer da pesquisa, em razão dos direcionamentos estabelecidos pelo Comitê de Ética da Universidade.
} 


\section{RESULTADOS}

Presidente Prudente é um município brasileiro no interior do estado de São Paulo (Figura 01), que está localizado a oeste de sua capital, distante $558 \mathrm{~km}$ da cidade de São Paulo. Segundo dados do IBGE, sua população é de 207.610 habitantes (considerando dados do último censo em 2010), sendo então o 36으 mais populoso município do Estado de São Paulo e primeiro de sua microrregião (DIÁRIO OFICIAL DA PREFEITURA DE PRESIDENTE PRUDENTE, 2021).

Figura 01. Localização do município de Presidente Prudente no Estado de São Paulo.

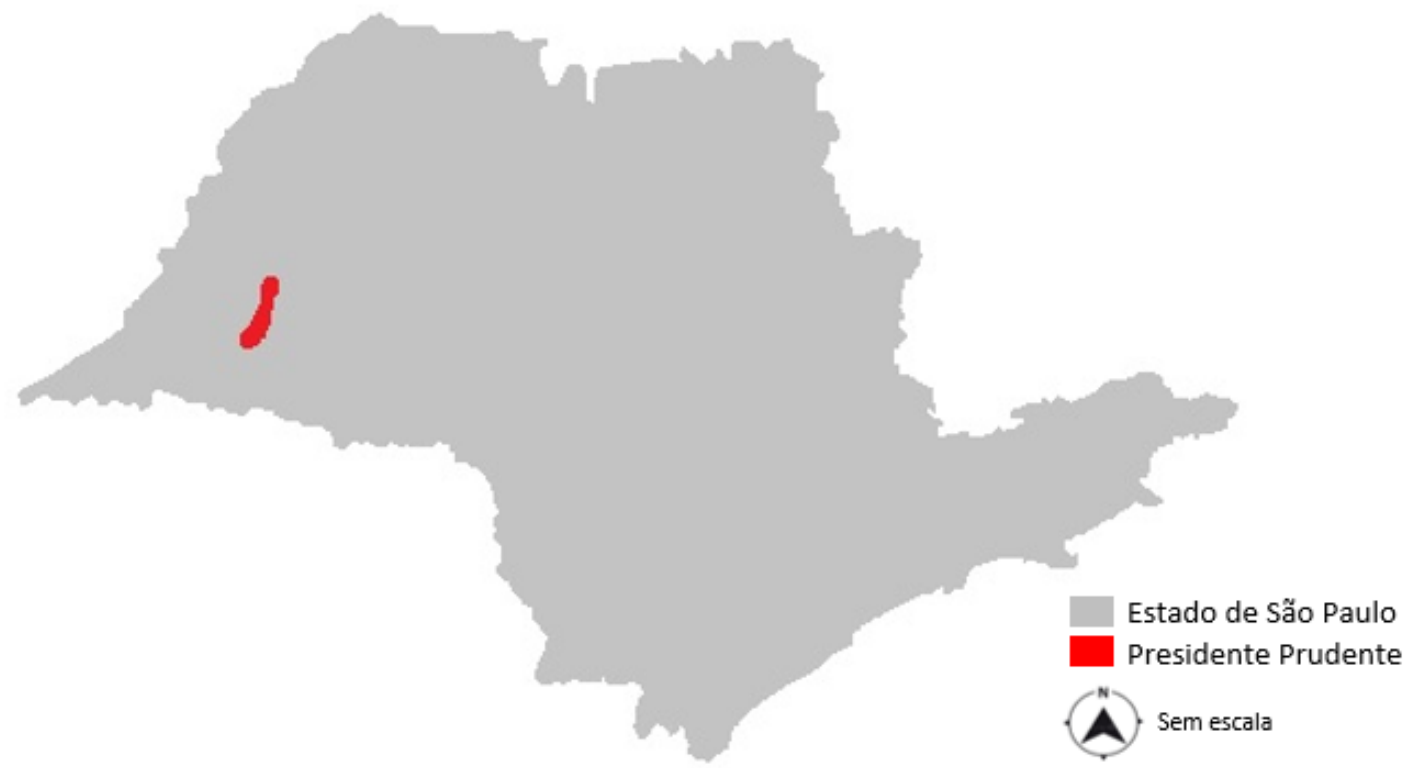

Fonte: Google Earth (2020), editado pelos autores (2021).

Como explica Celeste et al. (2015), a sua história começa bem antes de sua organização como uma cidade em si, iniciada em 1917, com o estabelecimento da Estrada de Ferro Sorocabana. Durante ainda o século XIX, grandes latifundiários do café se dirigiram para o oeste paulista em busca de novas terras. Como nessa região as terras ainda eram novas e boas para as plantações, muitas pessoas foram atraídas, criando assim as primeiras vilas, apesar das grandes dificuldades enfrentadas pelos primeiros colonos por causa da ausência de infraestrutura.

Com o estabelecimento da via férrea e das vilas Marcondes e Goulart, em homenagem aos primeiros colonizadores, a cidade cresceu $o$ suficiente para ganhar autonomia, enquanto município em novembro de 1921, quando oficialmente o governador Washington Luiz assinou o decreto criando o Município de Presidente Prudente. A cidade, em seus primeiros anos, estava concentrada ao longo da ferrovia, e as primeiras expansões que ocorreram até a década de 40 se localizavam ao redor dos núcleos originários, como é o caso da Vila Furquim e do Bairro do Bosque (SPOSITO, 1991).
Mas foi a partir da década de 60 que Presidente Prudente começou a passar por uma maior expansão horizontal, à medida que eram implantados novos loteamentos, principalmente na zona sudoeste da cidade, sendo o primeiro deles o bairro Jardim Bongiovani, estabelecido em 1962. Porém, uma condição físico-geográfica desinteressou os possíveis compradores de seus lotes: além dos altos preços e a falta de infraestrutura, o Córrego do Veado estava localizado entre o núcleo da cidade e o Jardim Bongiovani, o que dificultava o acesso dos moradores à cidade (SPOSITO, 1983).

Por conta dos interesses econômicos e da necessidade de se ocupar aquela área, foram realizadas diversas obras de infraestrutura (Figura 02), e dentre elas, a canalização do Córrego do Veado (entre os anos de 1973 e 1974), com posterior revitalização e implantação do Parque do Povo, o que valorizou a área e incentivou sua ocupação pelas pessoas de classes sociais mais elevadas (SPOSITO, 1983). 
Figuras 02 e 03. Comparativo entre o Parque do Povo na década de 70 e nos dias atuais em Presidente Prudente.
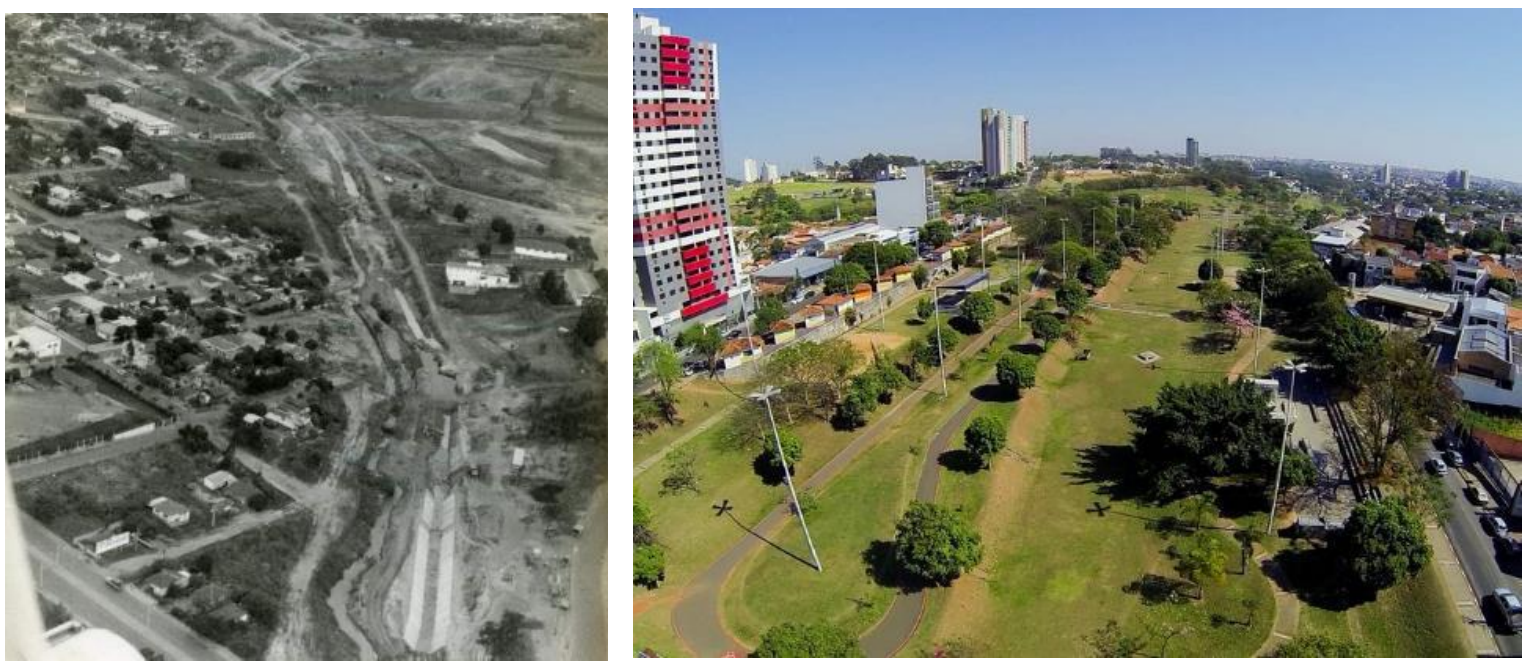

Fontes: Jornal O Imparcial (2020); Globo Esporte (2017).

Até então, a área do atual Parque do Povo não era um local atrativo, como é hoje (Figura 03); antes da canalização do Córrego do Veado e de sua transformação em parque, ele era um local de esgoto a céu aberto, pois os moradores da cidade despejavam lixo e dejetos. A área era, até então, um delimitador do perímetro da cidade (SILVA; FAGUNDES, 2018).

Atualmente, 2021, o Parque do Povo está localizado próximo ao centro comercial de Presidente Prudente (Figura 04) e é conhecido por ser uma extensa área de lazer, com cerca de $6 \mathrm{~km}$ de extensão, dispondo de muitas áreas verdes e equipamentos públicos, como pistas de skate, conjuntos desportivos, ciclovias, campo de futebol, quiosques e playground. O parque é circundado por importantes vias da cidade, como as avenidas da Saudade, Coronel José Sores Marcondes, Brasil, 11 de Maio, Quatorze de Setembro, Manoel Goulart e a Celestino José Figueiredo.

Ele também possui variedade $\mathrm{e}$ quantidade expressiva de espécies arbóreas, o que o torna atrativo e termicamente confortável em alguns pontos, atraindo assim muitas pessoas durante toda a semana, que usam o parque como "academia a céu aberto", praticando exercícios físicos como corrida, caminhada, entre outros (MORELLO, 2019).

Figura 04. Mapa de Presidente Prudente com o Parque do Povo em destaque.
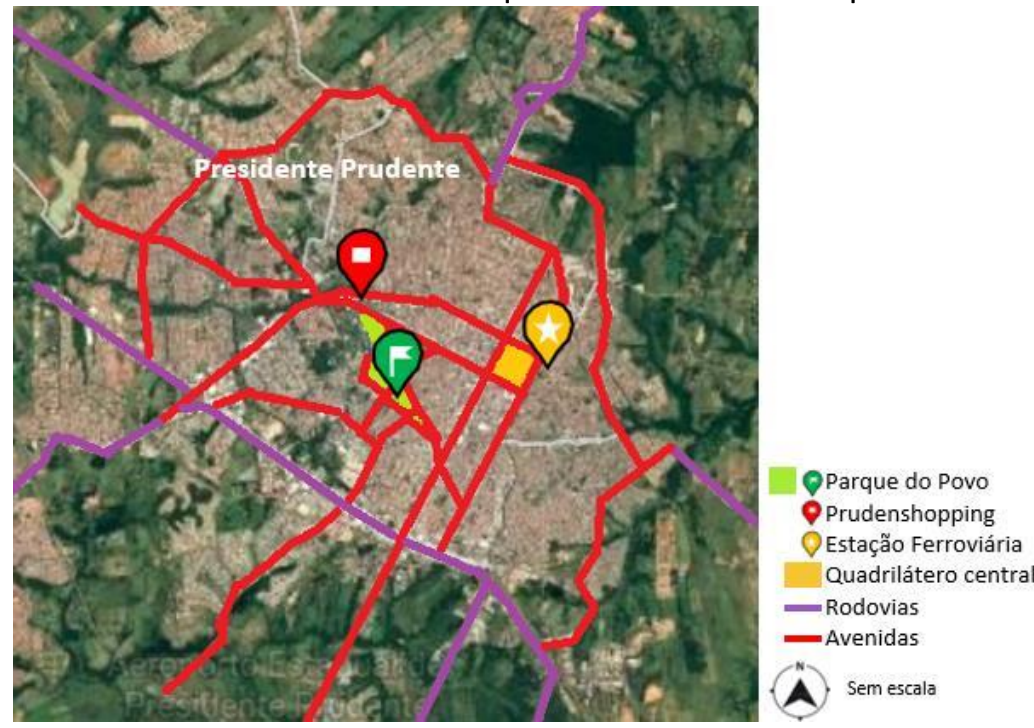

Fonte: Google Earth (2020), editado pelos autores (2021). 
O Parque do Povo pode ser dividido em seis trechos (Figura 05), cada um com diferentes equipamentos e funções. $O$ primeiro trecho, mais próximo do Prudenshopping, possui espaços para caminhada, alguns quiosques (que dão suporte a Universidade Estadual Paulista "Júlio de Mesquita Filho" (UNESP), universidade que fica de frente com o parque) e áreas de permanência, que são frequentemente ocupadas por jovens; essa permanência é facilitada pela boa arborização dessa parte do parque, além da proximidade com a Avenida Manoel Goulart.

Já o segundo trecho, onde inclusive se localiza o objeto de estudo da pesquisa, a Praça do Centenário, também permite caminhadas e possui alguns mobiliários infantis, mas no geral é uma área extensa e aberta, o que possibilita a prática de atividades ao ar livre e brincadeiras de soltar pipa, por exemplo. O terceiro trecho abriga, além de shows ao ar livre, alguns quiosques (o que determinou com que os lotes vizinhos abrigassem bares e restaurantes) e as pistas de skate, atraindo o público juvenil; esse trecho também é bastante arborizado e favorece a permanência de pessoas no local (Figura 05).

O quarto trecho do Parque do Povo apresenta um foco mais esportivo; além das quadras cobertas, igualmente possui um campo de futebol gramado e uma academia da terceira idade. $\mathrm{O}$ quinto trecho não possui equipamentos, apenas mobiliários como bancos e lixeiras, porém é a área mais sombreada, devido ao grande porte de suas árvores, favorecendo encontros e atividades que não exigem mobiliários fixos. E, por último, o sexto trecho é a parte mais plana de todo o parque, que além de possuir espaços de permanência e áreas para caminhada, abriga outra academia da terceira idade e alguns mobiliários infantis (Figura 05).

Figura 05. Mapa do Parque do Povo com a Praça do Centenário demarcada em Presidente Prudente.

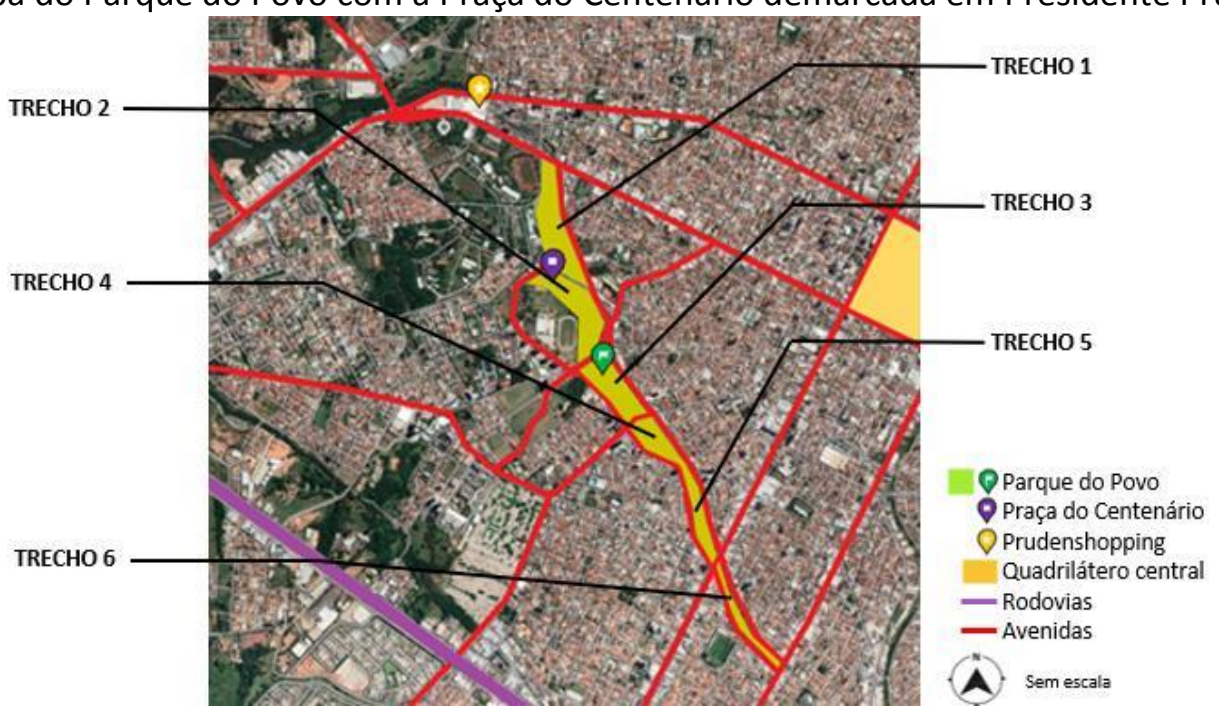

Fonte: Google Earth (2020), editado pelos autores (2021).

Voltando ao objeto de estudo, a Praça do Centenário (marcada na Figura 06), como já mencionado anteriormente, integra o segundo trecho do Parque do Povo, e é uma área de lazer ao norte do parque. A praça foi construída para homenagear o aniversário de 100 anos de Presidente Prudente, em 2018, já que a área onde ela foi edificada não possuía nenhum equipamento urbano. A partir de levantamentos in loco, foi possível notar que ela possui fins mais educativos, pois apresenta diversos elementos que buscam homenagear a história da cidade.
Antes da construção da praça, o terreno abrigava os circos e parques de diversão itinerantes que passavam pela cidade de tempos em tempos. Querendo ou não, esses serviços foram suspensos por um tempo e remanejados posteriormente e, por atender majoritariamente o público infantil, acabou por os afetar diretamente. 
Figura 06. Localização da Praça do Centenário no Parque do Povo em Presidente Prudente.

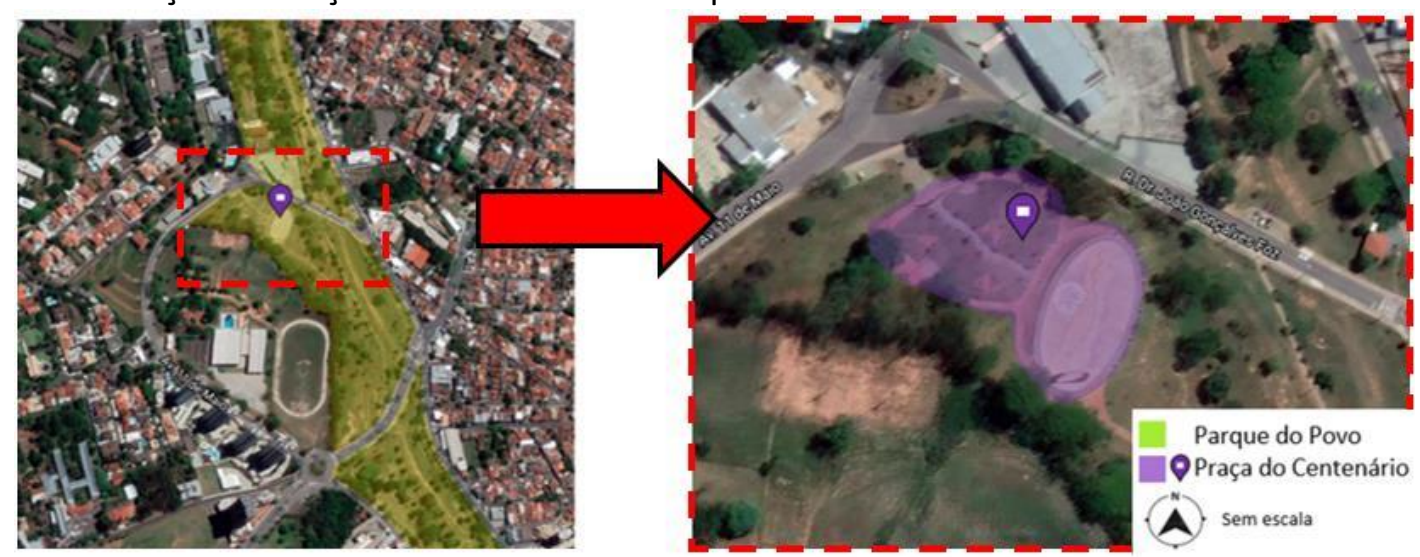

Fonte: Google Earth (2020), editado pelos autores (2021).

Além disso, a Praça do Centenário possui uma área total de 24 mil metros quadrados e foi projetada por um arquiteto urbanista da Secretaria Municipal de Planejamento. Um de seus grandes destaques é um monumento em concreto aparente em homenagem aos coronéis Marcondes e Goulart. Ela também possui em alto relevo no piso uma grande rosa dos ventos, em conjunto a um grande mapa que contém a cidade, os distritos e os municípios vizinhos (marcados na Figura 07) (DIÁRIO OFICIAL DA PREFEITURA DE PRESIDENTE PRUDENTE, 2018).

Figura 07. Imagem aérea da Praça do Centenário, com elementos marcados.

Fonte: Google Earth (2020), editado pelos autores (2021).

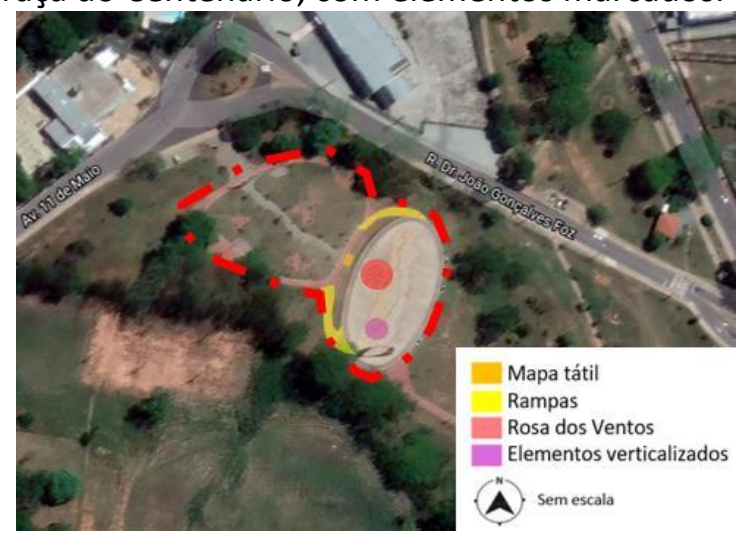

Porém, apesar de interessante e com pouco tempo de inauguração, possivelmente no projeto da praça não foram pensados parâmetros para estimular as crianças, já que, durante o levantamento in loco, não foi observado mobiliários especificamente infantis. Essa questão chama a atenção, pois apesar de ser um projeto novo e de cunho educativo, não foi pensado para acolher as crianças. Não existem espaços planejados especificamente para esse público, apesar da crescente necessidade de se fazê-los. Por consequência, foi observado que a Praça do Centenário não é muito utilizada por crianças, e isso se deve a alguns fatores:
O primeiro deles se deve à ausência de atrativos para essa faixa etária. A praça está inserida no Parque do Povo, uma grande área pública de lazer que, ao longo do seu percurso, possui playgrounds, equipamentos esportivos, e outras áreas de maior uso, como nos trechos dois e seis; o que faz com que os pais, ao decidirem levar seus filhos para brincar ao ar livre, optem por estas áreas do parque ao invés da Praça do Centenário, que efetivamente não tem nenhum espaço planejado para eles.

Segundo que, apesar da praça contar com equipamentos e monumentos com o propósito educativo, eles não são de fácil compreensão, 
seja para os adultos ou até mesmo para as crianças, o que acaba não sendo elemento de construção da identidade desses indivíduos, muito menos estimulante às interações sociais e culturais. E, por último, embora ela tenha infraestrutura adequada, a praça tem muitas falhas que desestimulam a permanência em sua área, como por exemplo a má arborização, a ausência de bebedouros e banheiros.

A pesquisa, portanto, aborda esses e outros aspectos nos próximos parágrafos, dando também destaque para os sinais de abandono, pois a Praça do Centenário já os exibe, fruto do descaso tanto das pessoas, quanto do município, já que, segundo informações no Portal de Notícias G1, de Presidente Prudente (2020), em 2019 e 2020, ela sofreu ações de vandalismo.

\section{DISCUSSÃO}

Como já apontado, a Praça do Centenário foi inaugurada em 2018, com finalidade histórica, conforme já destacado. No entanto, foi observado, nos levantamentos in loco e a partir de notícias locais, que ela é pouco utilizada, com exceção do período noturno (Figura 08) e nos fins de semana, por jovens, e durante os raros eventos promovidos pela população da cidade (é claro, voltados para o público adulto), como o Festival Diversonoridade, que ocorreu em abril de 2019, segundo matéria do Portal de Notícias G1, de Presidente Prudente (2019).

Figura 08. A Praça do Centenário sendo utilizada a noite.

Fonte: Globoplay (2018).

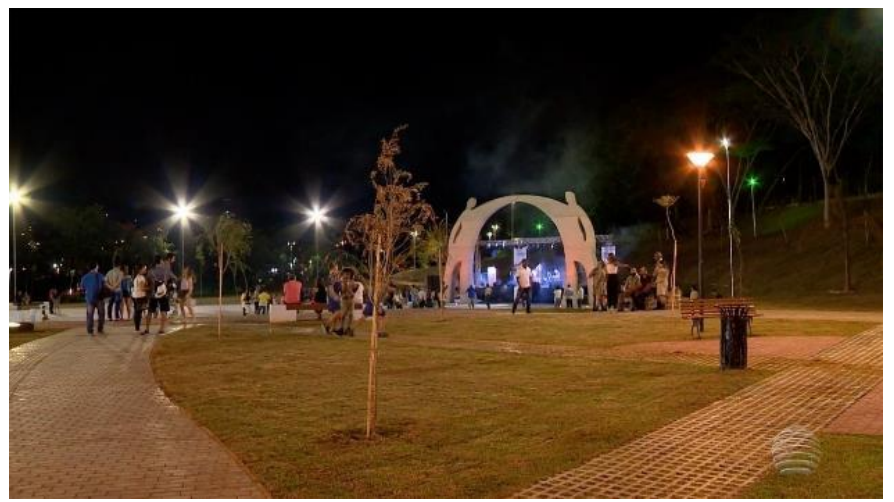

A partir do levantamento in loco, foi verificado e analisado a presença, a quantidade e a qualidade de mobiliários, iluminação, pavimentação, áreas verdes, arborização, sinalização e acessibilidade. Assim, nota-se que a praça tem boa infraestrutura, porém o uso inadequado, unido à falta de manutenção regular, tem repercutido em sinais significativos de abandono. Essas informações levantadas foram reunidas em uma tabela (Tabela 01) para facilitar a compreensão de seu estado geral de conservação para depois correlacionar com o potencial de uso de crianças. 
Tabela 01. Levantamento qualitativo e quantitativo da Praça do Centenário e seus mobiliários.

\begin{tabular}{|c|c|c|c|c|}
\hline & POSSUI & QUANTIDADE & QUALIDADE & DESCRIÇÃO \\
\hline ACESSIBILIDADE & Sim & Em toda a praça & Razoável & $\begin{array}{l}\text { Piso tátil e mapa tátil, porém rampas } \\
\text { inadequadas }\end{array}$ \\
\hline ARBORIZAÇÃO & Sim & $\begin{array}{l}9 \text { adultas } \\
53 \text { mudas }\end{array}$ & Ruim & Pouco sombreamento \\
\hline ÁREAS VERDES & Sim & $40,74 \%$ & Razoável & Quantidade boa, mas sem cuidado \\
\hline $\begin{array}{c}\text { ÁREAS } \\
\text { PAVIMENTADAS }\end{array}$ & Sim & $59,26 \%$ & Boa & Piso intertravado em bom estado \\
\hline ILUMINAÇÃO & Sim & 36 postes & Boa & Iluminação adequada, uso de LED \\
\hline MOBILIÁRIOS & Sim & $\begin{array}{l}31 \text { bancos } \\
6 \text { lixeiras }\end{array}$ & Razoável & $\begin{array}{c}\text { Boa quantidade, mas precisa de } \\
\text { manutenção }\end{array}$ \\
\hline $\begin{array}{l}\text { MOBILIÁRIOS } \\
\text { EDUCACIONAIS }\end{array}$ & Sim & 1 & Razoável & $\begin{array}{l}\text { Mapa da região, mais conceitual; } \\
\text { porém não é intuitivo }\end{array}$ \\
\hline $\begin{array}{l}\text { MOBILIÁRIOS } \\
\text { ESPORTIVOS }\end{array}$ & Não & 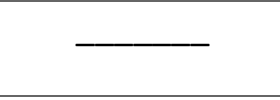 & _ & 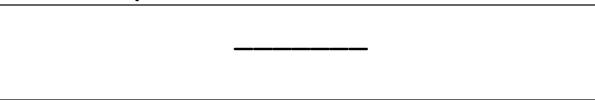 \\
\hline $\begin{array}{l}\text { MOBILIÁRIOS } \\
\text { INFANTIS }\end{array}$ & Não & _ & ـ & \\
\hline SINALIZAÇÃO & Sim & 2 & Razoável & Apenas placas de estacionamento \\
\hline
\end{tabular}

Fonte: Arquivo dos autores (2021).

A Praça do Centenário foi projetada para ser acessível, já que possui piso tátil e mapa tátil (Figura 11) com braile. Porém, a inclinação de suas rampas (Figura 09) é inadequada, conforme a NBR 9050 (2020), e foi observado a presença de piso de pedra portuguesa (Figura 10) em algumas partes, o que dificulta a circulação de pessoas cadeirantes. As partes onde tem-se o piso intertravado até que está em bom estado de conservação.

Figuras 09 e 10. Rampas inadequadas e piso de pedra portuguesa na Praça do Centenário.

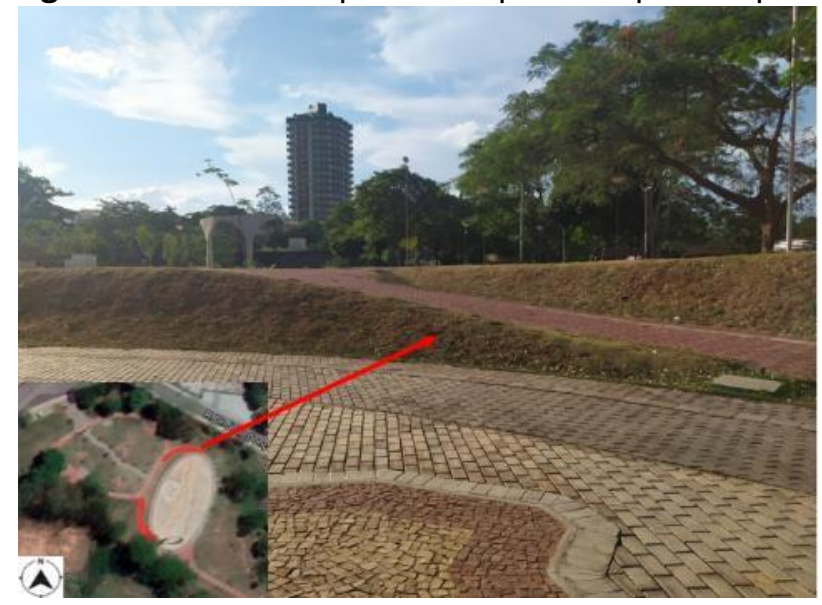

Fontes: Google Earth (2020), editado pelos autores (2021).

Além disso, após alguns episódios de vandalismo, o mapa tátil com braile foi arrancado

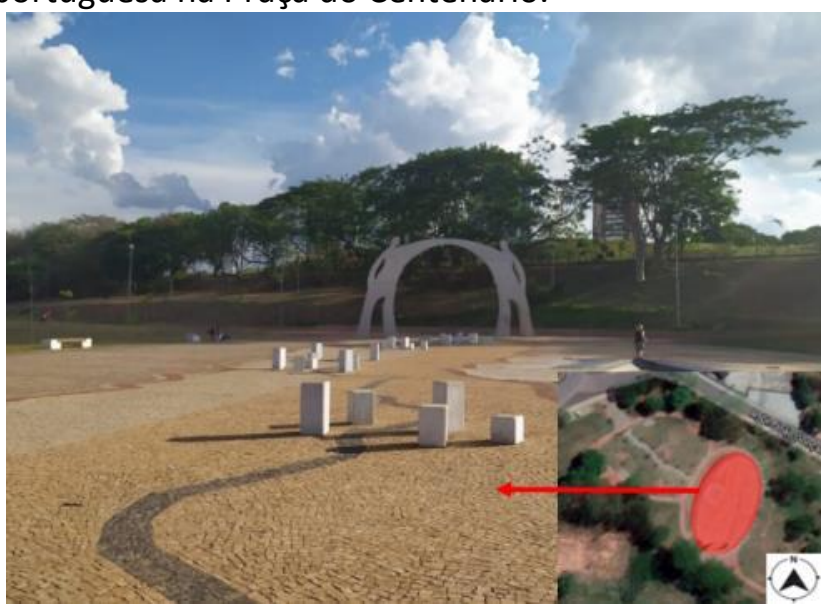

(Figura 11) e, até a finalização da pesquisa, ele não havia sido substituído. 
Figura 11. Mapa tátil antes e depois de ser danificado na Praça do Centenário.

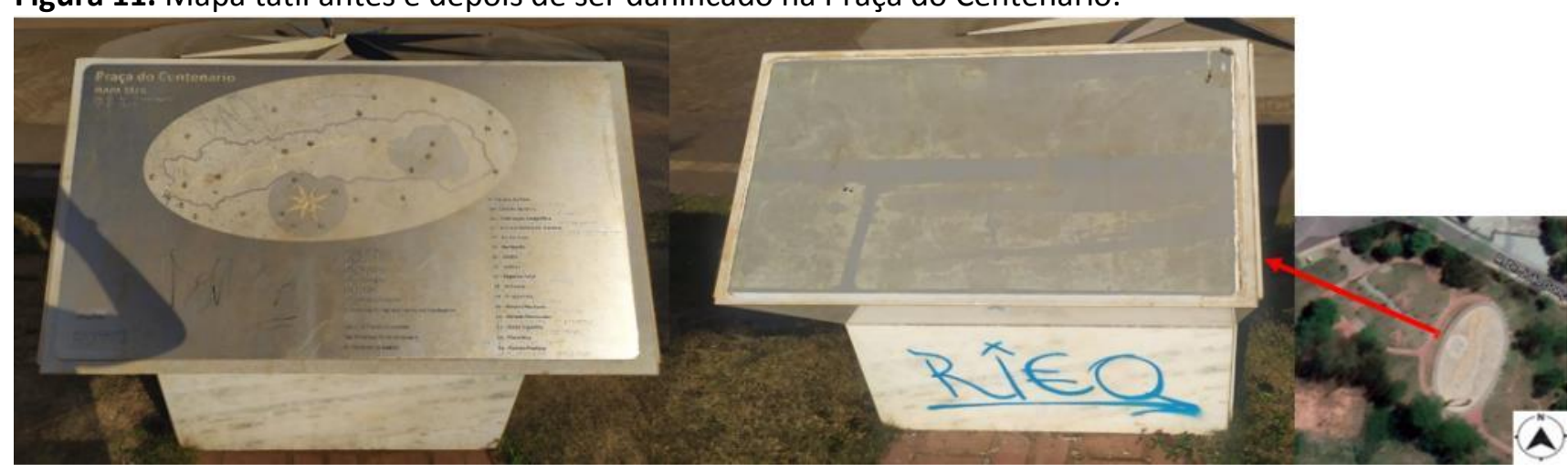

Fonte: Google Earth (2020), editado pelos autores (2021).

Durante os levantamentos in loco foi verificado que havia, no total, 62 árvores, sendo nove delas adultas e as outras 53 eram mudas bem jovens. A arborização da praça (Figura 12) é deficitária, já que as árvores adultas estão nas extremidades e na sua extensão só é possível encontrar mudas jovens que, além de não serem muito resistentes às intempéries e as ações de vandalismo, não contribuem para o sombreamento do local, tornando a permanência muito difícil em dias de calor.

Figura 12. Insuficiência de arborização na Praça do Centenário.

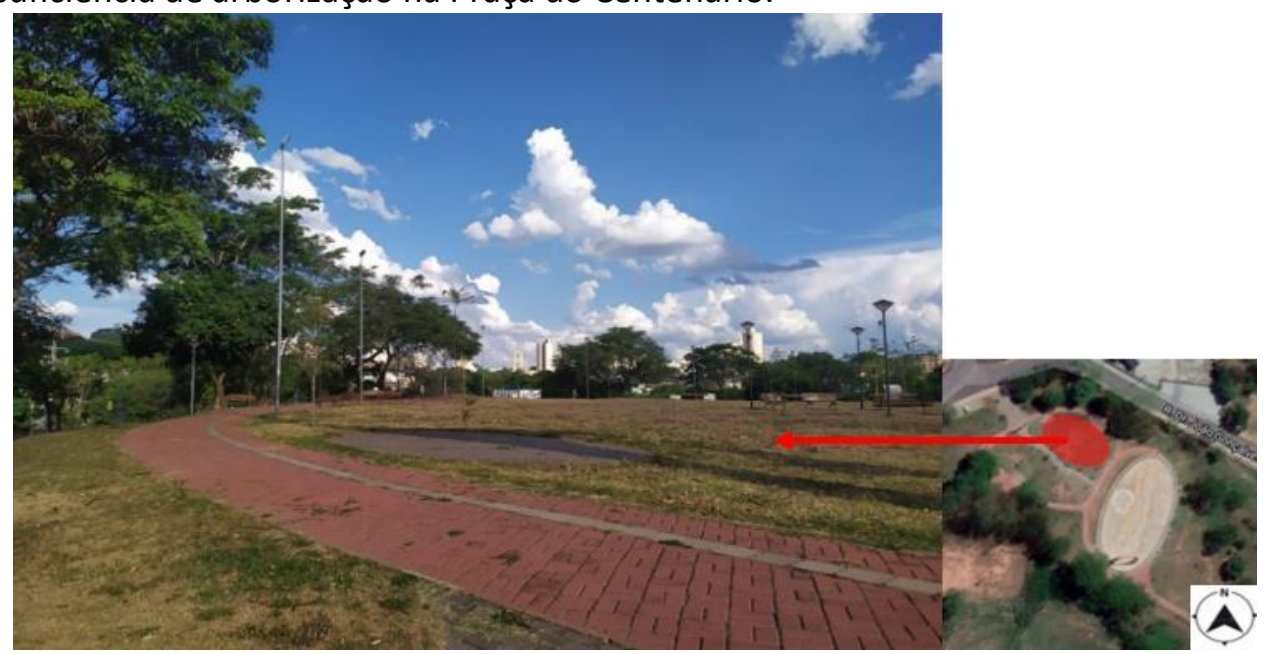

Fonte: Google Earth (2020), editado pelos autores (2021).

Como é possível observar na Tabela 01 e na Figura 13, a Praça do Centenário até possui uma extensa área gramada, porém, a ausência de sombreamento e de grandes árvores impossibilita sua permanência e limita seus espaços e brincadeiras, já que na ausência de mobiliários específicos, as crianças tendem a brincar com o que está disponível no seu entorno. 
Figura 13. Incidência solar e insuficiência da arborização no período da tarde na Praça do Centenário.

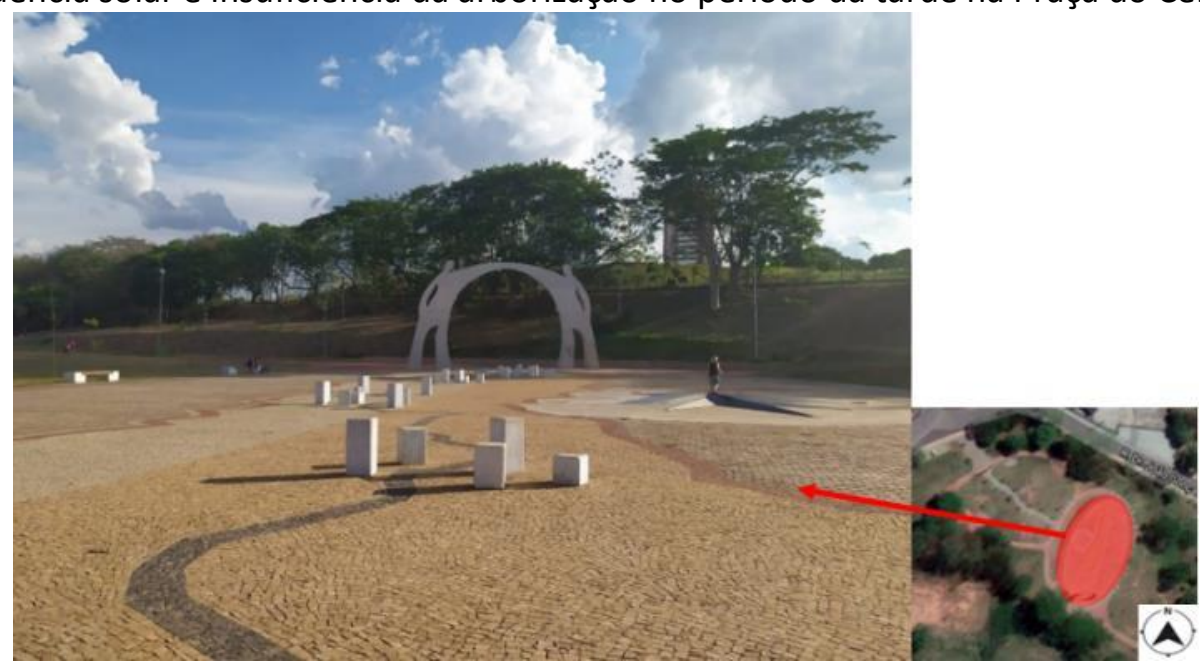

Fonte: Google Earth (2020), editado pelos autores (2021).

A iluminação é boa, devido às lâmpadas de LED; como o horário de maior circulação de pessoas é a noite, isso se torna imprescindível para melhorar a segurança para seus usuários. Tendo em vista que não há muitas árvores, não acontecem áreas de penumbra e mal iluminadas pelo conflito entre arborização e iluminação. Os mobiliários comuns, como bancos e lixeiras não são de má qualidade, porém necessitam de constante manutenção e cuidado. Os bancos que possuem partes em madeira (Figura 14),

Figuras 14 e 15. Banco e lixeira da Praça do Centenário.

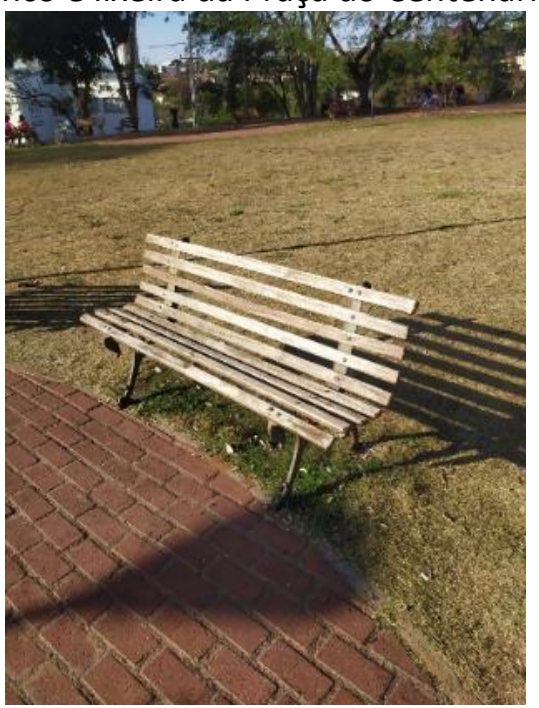

Fontes: Arquivo dos autores (2020).

Foram observados alguns elementos construtivos com finalidade educativa, como o grande mapa no piso, com a rosa dos ventos e os elementos verticais, que funcionam como bancos. Porém, como já mencionado, eles são de precisam ser envernizados de tempos em tempos para minimizar seu desgaste. Já as lixeiras (Figura 15) não são muito práticas, visto que seu design não consegue conter todo o lixo.

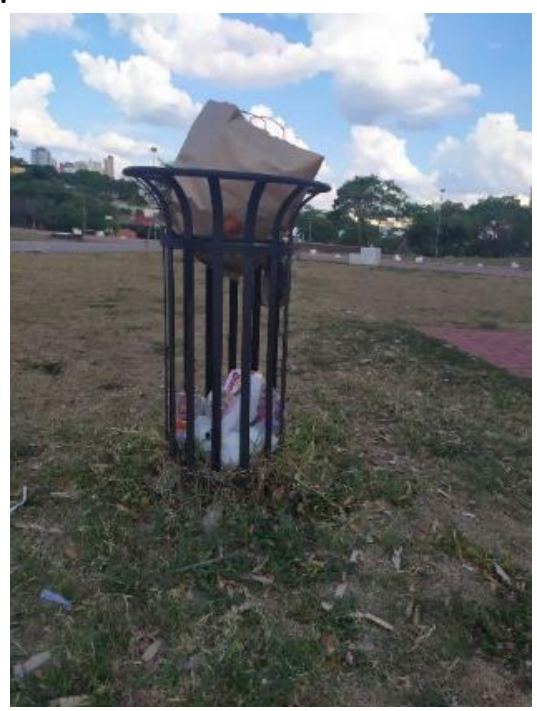

difícil compreensão, já que o mapa tátil tem uma legenda pouco clara, dificultando a visibilidade. Algumas crianças brincam de subir nesses mobiliários (Figura 16), devido à falta de brinquedos infantis, mas tal atividade é perigosa, 
já que elas podem cair. Durante a pesquisa, parte desses elementos também foi retirada durante atos de vandalismo (Figuras 17 e 18) e, assim como no caso do mapa, não foram substituídos.

Figura 16. Crianças brincando em cima da rosa dos ventos na Praça do Centenário.

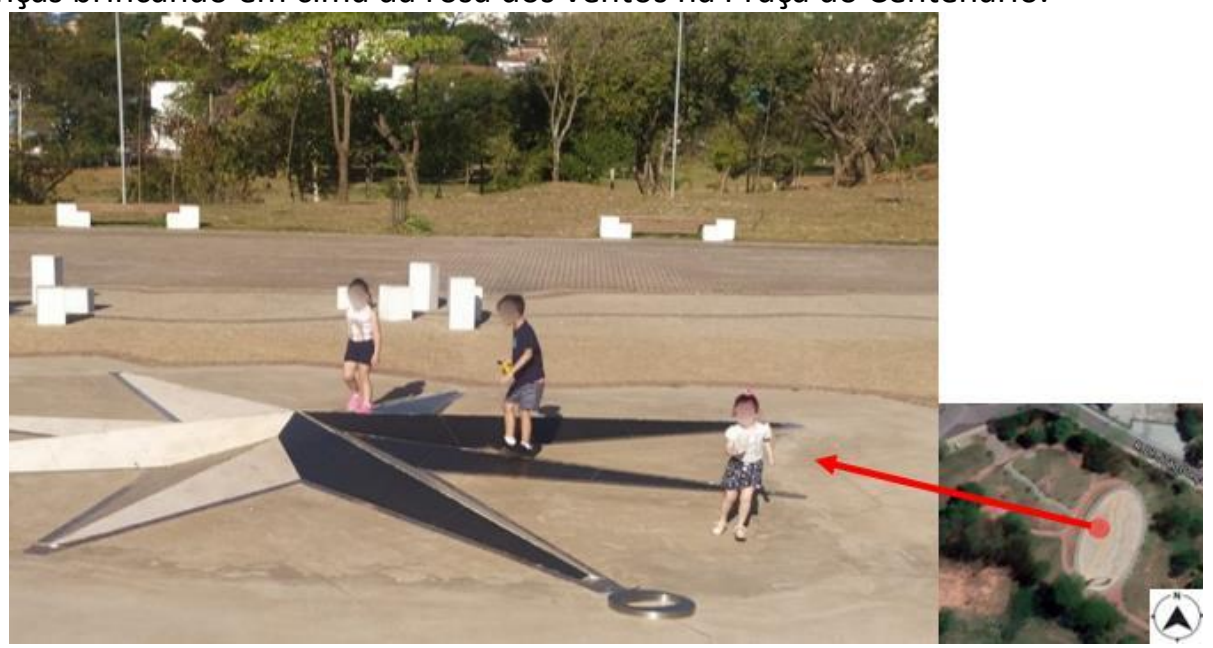

Fonte: Google Earth (2020), editado pelos autores (2021).

Figuras 17 e 18. Rosa dos ventos e elementos verticais vandalizados na Praça do Centenário.
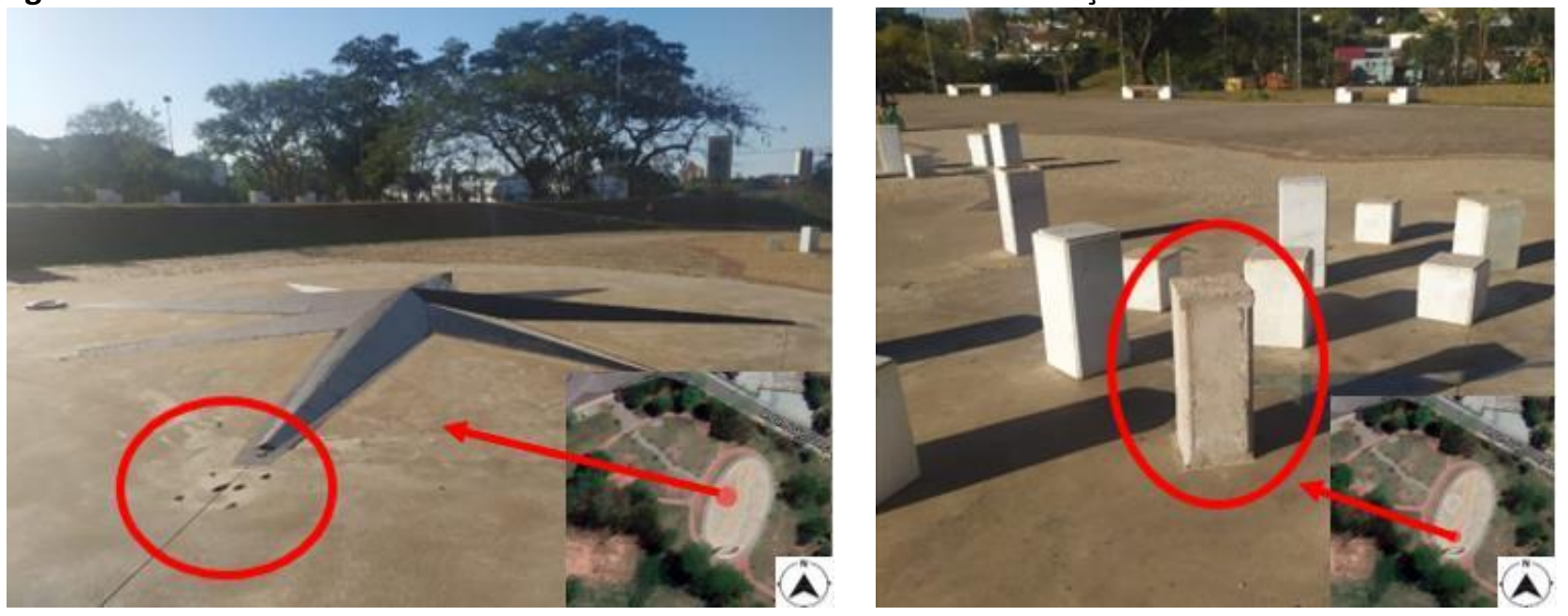

Fontes: Google Earth (2020), editado pelos autores (2021).

A Praça do Centenário não possui mobiliários infantis e esportivos, o que dificulta a permanência das famílias por um longo período, e restringe seus usuários, já que muitos optam por outras áreas do Parque do Povo, melhores assistidas nesse quesito. Durante os levantamentos in loco, foram observados pais com seus filhos passeando pela praça, mas as crianças levavam consigo bicicletas (figura 19), jogos e entre outros brinquedos, pois, com a falta de mobiliários próprios para a idade, ou elas brincam com os elementos citados anteriormente, ou acabam entediadas rapidamente. 
Figura 19. Criança andando de bicicleta na Praça do Centenário.

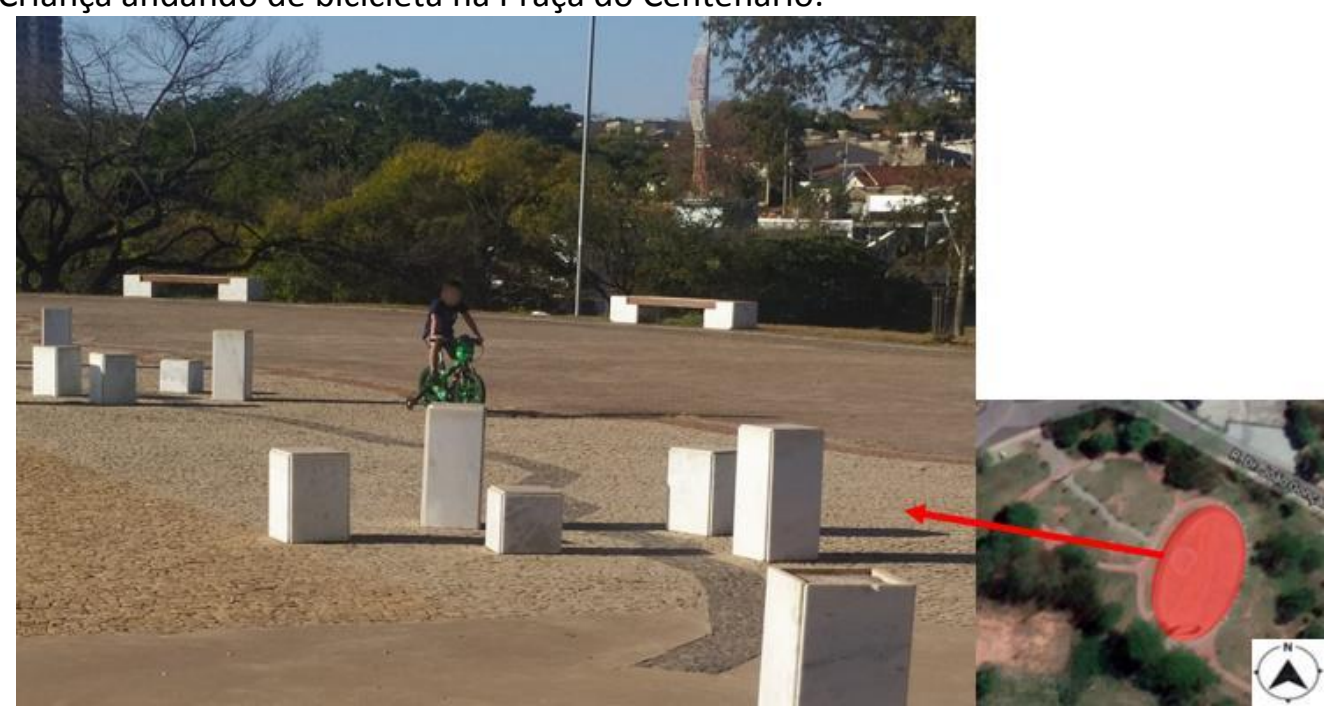

Fonte: Google Earth (2020), editado pelos autores (2021).

Considerando a importância da praça, era fundamental que fosse criada uma área para esse público, aumentando, assim, o tempo de permanência e criando um vínculo maior entre a criança e a Praça do Centenário em Presidente Prudente - SP.

É possível afirmar que a Praça do Centenário apresenta um projeto urbano com pontos interessantes, mas a falta de manutenção e os vandalismos prejudicam o seu estado geral. Esses problemas, aliados a falta de arborização e o seu déficit em mobiliários infantis, acarretam que ela não seja receptiva às crianças, restringindo suas ações e as colocando em situações desagradáveis, como o calor e o risco de queda (que os elementos construtivos acabam ocasionando).

Dentro do que foi observado e levantado, é necessário compreender a importância de se pensar os espaços públicos para atender as necessidades físicas e sociais das crianças, para que então políticas públicas possam ser elaboradas e implantadas a fim de resgatar a sua função potencializadora de encontros. As crianças da era contemporânea tem seu desenvolvimento social prejudicado pelo afastamento e isolamento delas a áreas restritamente infantis e controladas, tendo em vista que as crianças estão sendo prejudicadas pelo afastamento e isolamento.

Infelizmente, a situação observada durante essa pesquisa foi que, apesar de ser um espaço público, as problemáticas apontadas da Praça do Centenário atrapalham e prejudicam as relações que poderiam ser despertadas nas crianças, porque o ambiente não é adequado e acolhedor às suas necessidades. Por maior que tenha sido seu investimento, é falha no que tange a sua função educadora e cívica, de modo que o poder público deveria rever seus aspectos para propiciar um uso que contemple mais as crianças.

Poderiam ser realizadas, no caso da Praça do Centenário, implementações para melhorar o estado qualitativo da praça, a fim de auxiliar no desenvolvimento infantil. Soluções como a implantação de mobiliários adequados ao público infantil, inserção de exemplares arbóreos mais desenvolvidos, além da manutenção periódica dos mobiliários existentes, são possíveis caminhos para atender às necessidades das crianças e contribuir para uma maior permanência do público na praça.

\section{REFERÊNCIAS}

ASSOCIAÇÃO BRASILEIRA DE NORMAS TÉCNICAS. Acessibilidade a edificações, mobiliário, espaços e equipamentos urbanos: NBR 9050. Rio de Janeiro: ABNT, 2015.

\section{ASOCIACIÓN INTERNACIONAL DE CIUDADES EDUCADORAS. Ciudad Educadora. 2012. Disponível \\ em: \\ http://www.bcn.cat/edcities/aice/estatiques/esp anyol/sec_educating.html. Acesso em: 03 jun. 2021.}

BRASIL. Emenda constitucional $\mathrm{N}^{\circ} 65$, de 13 de julho de 2010. Altera a denominação do Capítulo VII do Título VIII da Constituição Federal e 
modifica o seu art. 227, para cuidar dos interesses da juventude. Constituição (1988). Diário Oficial [da] República Federativa do Brasil, Brasília, DF, 13 jul. 2010. Disponível em: http://www.planalto.gov.br/ccivil_03/constituica o/constituicao.htm. Acesso em: 26 jun. 2021.

BRASIL. Lei $N^{\circ}$ 8.069, de 13 de julho de 1990. Dispõe sobre o Estatuto da Criança e do Adolescente

e dá outras providências. Estatuto da Criança e do Adolescente. Diário Oficial [da] República Federativa do Brasil, Brasília, DF, 16 jul. 1990. Disponível em: http://www.planalto.gov.br/ccivil_03/LEIS/L8069 .htm\#art266. Acesso em: 10 jul. 2021.

CELESTE, M.; FERNANDES M.; HAGASHINAGA, A.; MARIA, Y. R. Presidente Prudente - SP: Um pouco de Memória Histórica. Colloquium Humanarum, Presidente Prudente, v. 12, n. Especial, p. 337341, 2015. Disponivel em: http://www.unoeste.br/site/enepe/2015/suplem entos/area/Humanarum/Arquitetura\%20e\%20Ur banismo/PRESIDENTE\%20PRUDENTE\%20\%E2\%80 \%93\%20SP\%20UM\%2OPOUCO\%20DE\%20MEMO RIA\%2OHIST\%C3\%93RICA.pdf. Acesso em: 22 jul. 2021.

DIÁRIO OFICIAL DA PREFEITURA DE PRESIDENTE PRUDENTE. A cidade. Presidente Prudente, SP, 2021. Disponível em: http://www.presidenteprudente.sp.gov.br/site/a cidade.xhtml. Acesso em: 16 maio 2021.

DIÁRIO OFICIAL DA PREFEITURA DE PRESIDENTE PRUDENTE. Praça do Centenário é entregue nesta sexta-feira, com shows de artistas prudentinos. Presidente Prudente, SP, 13 abril 2018. Disponível em: http://www.presidenteprudente.sp.gov.br/site/n oticias.xhtml?cod=39410. Acesso em: 10 jul.2021.

DIAS, M. S.; FERREIRA, B. R. Espaços públicos e infâncias urbanas: a construção de uma cidadania contemporânea. Revista Brasileira de Estudos Urbanos e Regionais, Rio de Janeiro, v. 17, n. 3, p. 118-133, dez. 2015. https://doi.org/10.22296/2317-

$\underline{1529.2015 v 17 n 3 p 118}$

G1 PRESIDENTE PRUDENTE. Praça do Centenário é alvo de vandalismo em Presidente Prudente. 12 de junho de 2020. Disponível em: https://g1.globo.com/sp/presidente-prudenteregiao/noticia/2020/06/12/praca-do-centenarioe-alvo-de-vandalismo-em-presidenteprudente.ghtml. Acesso em: 10 jul. 2021.

G1 PRESIDENTE PRUDENTE. Festival Diversonoridade apresenta atrações musicais neste fim de semana na Praça do Centenário. 20 de abril de 2019. Disponível em: https://g1.globo.com/sp/presidente-prudenteregiao/noticia/2019/04/20/festival-

diversonoridade-apresenta-atracoes-musicaisneste-fim-de-semana-na-praca-docentenario.ghtml. Acesso em: 20 maio 2021.

GADELHA, J. B. Instrumentos projetuais de Arquitetura e Urbanismo como agentes transformadores, tendo como parâmetro a escala da criança. In: COLÓQUIO INTERNACIONAL IMAGINÁRIO: CONSTRUIR E HABITAR A TERRA / DEFORMAÇÕES, DESLOCAMENTOS E DEVANEIOS (ICHT), 3., 2019, São Paulo. Anais Colóquio Internacional: ICHT III. USP, 2019. Disponível em: https://sites.usp.br/icht2019/wpcontent/uploads/sites/416/2019/07/Instrumento s-projetuais-de-Arquitetura-e-Urbanismo-comoagentes-transformadores-tendo-comopara\%CC\%82metro-a-escala-da-crianc\%CC\%A7a.pdf. Acesso em: 03 jul. 2021.

IBGE. Ministério do Planejamento, Desenvolvimento e Gestão. Censo demográfico. $2010 . \quad$ Disponível em: https://cidades.ibge.gov.br/brasil/sp/presidenteprudente/panorama. Acesso em: 18 maio 2021.

LOEB, R. M. Territórios Vulneráveis, Arquitetura e Urbanismo: estratégias contemporâneas de ação. 2019. Dissertação (Mestrado em Arquitetura e Urbanismo) - Universidade Presbiteriana Mackenzie, São Paulo, 2019.

LUZ, G. M. da; KUHNEN, A. O uso dos espaços urbanos pelas crianças: explorando o comportamento do brincar em praças públicas. Psicologia: Reflexão e Crítica, v. 12, n. 3, p. 172184, 2010.

LUZ, G. M. da; KUHNEN, A. O uso dos espaços urbanos pelas crianças: explorando o comportamento do brincar em praças públicas. Psicologia: Reflexão e Crítica [online]. v. 26, n. 3, p. 552-560. 2013. https://doi.org/10.1590/S010279722013000300015 
MEKIDECHE, T. Espaços para crianças na cidade de Argel: um estudo comparativo da apropriação lúdica dos espaços públicos. In: TASSARA, E. T.; RABINOVICH, E. P. (ed.). Psicologia e ambiente. São Paulo: Educ, 2004. p. 143-167.

MEIRA, A. M. Olhares das crianças sobre a cidade de Porto Alegre: infância contemporânea, psicanálise, educação e arte. 2011. Tese (Doutorado em Educação) - Universidade Federal do Rio Grande do Sul. Porto Alegre, RS, 2011.

MERLIN, J. R.; QUEIROZ, A. N. Espaços Públicos: suas potencialidades educadoras e a construção da cidadania. In: ENCONTRO DA ASSOCIAÇÃO NACIONAL DE PESQUISA E PÓS-GRADUAÇÃO EM ARQUITETURA E URBANISMO, 3., 2014, São Paulo. Anais [...]. São Paulo: ANPARQ, 2014. Disponível em: https://www.anparq.org.br/dvdenanparq-3/htm/Artigos/SC/ORAL/SC-EPC034_MERLIN_QUEIROZ.pdf. Acesso em: 03 jun. 2021.

MORELLO, T. Parque do Povo: point prudentino. O Imparcial, Presidente Prudente, 14 setembro $2019 . \quad$ Disponível em: https://www.imparcial.com.br/noticias/parquedo-povo-point-prudentino,29332. Acesso em: 13 mar. 2021.

NOSEK, H. S. A criança no espaço público da cidade de São Paulo: Diferenças e aproximações entre dois bairros: Jardim Lapenna e Itaim Bibi. 2018. Dissertação (Mestrado em Arquitetura e Urbanismo) - Universidade Presbiteriana Mackenzie. São Paulo, 2018.

OLIVEIRA, C. $O$ ambiente urbano e a formação da criança. São Paulo: Aleph, 2004.

PRESIDENTE PRUDENTE. Lei Complementar no 230/2018, de 27 de dezembro de 2017. Dispõe sobre a Lei do Plano Diretor do Município, e dá outras providências. Plano Diretor de Presidente Prudente. Diário Oficial [da] Cidade de Presidente Prudente, SP, Brasil, 27 dez. 2017. Disponível em: http://www.presidenteprudente.sp.gov.br/site/D ocumento.do?cod=45274. Acesso em: 10 jul. 2021.

SARMENTO, M. J. As culturas da infância nas encruzilhadas da Segunda Modernidade. In: CERISARA, A. B. Crianças e miúdos: perspectivas sócio pedagógicas da infância e educação. Porto: Asa Editores, 2004. p. 9-34.

SARMENTO, M. J. Infância e cidade: restrições e possibilidades. Educação, Porto Alegre, v. 41, n. 2 p. 232-240, maio/ago., 2018. https://doi.org/10.15448/1981-

$\underline{2582.2018 .2 .31317}$

SARMENTO, M. J. Apresentação do Dossiê Crianças e suas infâncias na cidade. Cadernos de Pesquisa em Educação, Vitória, v. 21, n. 49, p. 1-5, jan./jun. 2019. https://doi.org/10.22535/cpe.v21i49.26179

SILVA, L. D.; FAGUNDES, R. J. D. L. O processo de gentrificação do Parque do Povo: fatores que desencadearam este fenômeno social. Encontro de Iniciação Científica, Presidente Prudente, v. 14, n. 14, 2014. Disponível em: <http://intertemas.toledoprudente.edu.br/index. php/ETIC/article/view/7023>. Acesso em: 23 jul. 2021.

SPOSITO, M. E. B. O Chão em Presidente Prudente: a lógica da expansão territorial urbana. 1983. Dissertação (Mestrado em Geografia) Universidade Estadual Paulista, Rio Claro, 1983.

SPOSITO, M. E. B. O chão arranha o céu: a lógica da (re)produção monopolista da cidade. 1991. Tese (Doutorado em Geografia) - Universidade de São Paulo, São Paulo, 1991.

VICENTE, P. M. Novos olhares: uma leitura da cidade por suas crianças. 2018. Dissertação (Mestrado em Arquitetura e Urbanismo) Universidade de São Paulo. São Paulo, 2018. 